\title{
Editorial
}

\section{Estamos avaliando bem os candidatos à docência no ensino superior?}

Os dados oficiais do MEC indicam que há 50.000 vagas não preenchidas de professores de Física no Ensino Médio, em todo o país. Todos os anos, os cursos de licenciatura em Física formam pouco mais de 500 professores. Se supusermos mantida a situação atual, inclusive permanecendo vivos e trabalhando os atuais e futuros professores, sem aposentadorias, daqui a 100 anos ter-se-ia o número suficiente de professores de Física. Este dado é apenas uma caricatura chocante da situação do ensino de Física em nosso país, fruto de equívocos acumulados há tempos na conduta de sua política educacional, em vários apectos, entre outros, a valorização profissional, estímulo à formação continuada, padrão salarial digno, diminuição da carga didática excessiva sem prejuízo dos rendimentos. Com relação à política global, os professores universitários, além de espernear, podem apenas investir na qualidade de ensino dos cursos de licenciatura e participar de programas de formação continuada.

$\mathrm{O}$ ensino de Física universitário também se encontra em estado lastimável, e cabe a nós professores de Física no ensino superior a maior responsabilidade. Não temos cumprido nossa função primordial de formar bons físicos e/ou bons professores de Ensino Médio. Por várias razões, entre elas sermos avaliados profissionalmente apenas quanto à pesquisa científica que produzimos, temos relegado a segundo plano nossa principal função de formar pessoal qualificado em Física. Com o passar do tempo, esta distorção se auto-alimenta, se reproduz, o quadro já ruim se torna ainda pior. Nos concursos públicos de ingresso na carreira de professor universitário, tenta-se "avaliar" os candidatos apenas pela pesquisa científica que seriam capazes de produzir. Este tipo de "avaliação" não se sustenta nem mesmo na hipótese absurda de se pretender contratar um "bom apertador de parafuso" no laboratório de pesquisa experimental, ou um bom "calculador" para atuar no formalismo teórico: não há bons pesquisadores em Física que não sejam bons conhece- dores das bases conceituais sobre as quais a disciplina repousa.

O primeiro e mais importante quesito a ser avaliado num concurso público para professor universitário de Física é necessariamente o conhecimento das bases conceituais da Física, os conceitos mais fundamentais.

Destaquei a última frase num único parágrafo porque, por incrível que pareça, esta afirmação é contestada por vários colegas. Alega-se ser suficiente, num concurso público, a avaliação da performance do candidato como pesquisador, especificamente no tema a que se dedica naquele efêmero instante da carreira. Trata-se de uma interpretação equivocada, um perigo para todo o sistema universitário quando se reproduz no candidato, que se torna professor.

Compete a nós, professores universitários de Física, introduzirmos a prática de avaliar o conhecimento dos conceitos básicos nos concursos públicos de nossas universidades, como quesito eliminatório. A avaliação da performance do candidato nas atividades de pesquisa propriamente dita é evidentemente necessária, e vem em seguida. Cabe aos colegas mais imediatistas, ávidos de quadros especializados para continuar seu próprio projeto de pesquisa, compreender que isto só se consegue com bons profissionais, de formação ampla e completa. Faz parte da formação de bons quadros profissionais sinalizar ao jovem ingressante na carreira qual a competência que dele se espera.

Concursos com as idéias aqui alinhavadas já são realizados em alguns bons Institutos/Departamentos de Física em nossas universidades. Espero que se espalhem pelo país.

Paulo Murilo Castro de Oliveira Professor Titular I.F. da Universidade Federal Fluminense Vice-Presidente da SBF 